\title{
Stress and the level of perceived anxiety among mariners: the mediating role of marital satisfaction
}

\author{
Aleksandra Peplińska ${ }^{1}$, Maria Jeżewska ${ }^{2}$, Irena Leszczyńska ${ }^{2}$ Piotr Połomski ${ }^{1}$ \\ ${ }^{1}$ Institute of Psychology, University of Gdansk, Gdansk, Poland \\ ${ }^{2}$ Institute of Maritime and Tropical Medicine, Medical University of Gdansk, Gdansk, Poland
}

\begin{abstract}
ABTRACT
The challenges of professional life are becoming more and more demanding on people's private life, especially if a given profession requires many sacrifices and has negative consequences for one's physical and psychological health, as is the case of professional mariners. The purpose of this study is to attempt to verify the correlation between the quality of emotional bonds, manifested in marital satisfaction, and the level of stress and anxiety perceived by mariners. The study encompasses 210 mariners working on seagoing ships. The following research tools were employed for the purpose of the study: State-Trait Anxiety Inventory (STAl), Stress Experience Questionnaire (PS) and Well-matched Marriage Questionnaire (KDM). The results indicate that marital satisfaction is correlated with the level of stress and anxiety among mariners, constituting a stress inhibitor.
\end{abstract}

(Int Marit Health 2013; 64, 4: 221-225)

Key words: seafaring, mariners, work-related stress, marital satisfaction, family and work

\section{INTRODUCTION}

In a modern world of changing lifestyles, various spheres of human life permeate each other more and more, impacting the general quality of life [1]. The spheres of an individual's life in which such mutual relations are observed, most often include professional activity and personal/family life. Such relations can be negative, generating a series of conflicts, both in the work-family relation and in the family-work relation, as well as positive in nature. Challenges at work can positively influence the sphere of personal life, while personal life can positively influence the professional performance, for instance by serving as a buffer, helping the individual to cope with many challenges and issues, neutralising the level of perceived stress [2, 3].

The hermetic environment of the sea ship is widely considered to be highly stressful for its crew [4]. Analysis of the research material, obtained through numerous studies, indicates that many objective circumstances accompanying the mariner profession constitute high-level stress factors, although reactions differ depending on the coping abilities of the individual mariners $[5,6]$. Most common factors include: deprivation of basic human needs caused by separation from the family, loved ones and sexual partners [7]; social dangers correlated with tensions within a closed group and interpersonal conflicts [5]; danger of life or health loss on the ship [7]; limited selection of extra-professional activities during leisure time, limited freedom of movement and reduced privacy [6]; discomfort connected with uncomfortable physical conditions of work and life - heaving and swaying of the ship, vibrations, noise or weather changes; psychological overload connected with performing various professional activities in difficult atmospheric conditions [8]; frustrating situations, often resulting from improper work flow on the ship and at the port-dragging stays in the roadstead, unplanned extensions of the voyage, or waiting for one's replacement [9]. Research indicates that during their service on the ship, most mariners experience nearly constant, chronic emotional stress [4]. The source of this stress is long period of separation from loved ones, sexual deprivation and limited freedom during leisure time. Measurements revealed that chronic emotional stress increased proportionately to the duration of the voyage [10]. Sea isola-

Dr Maria Jeżewska, Clinic of Occupational and Internal Diseases, Institute of Maritime and Tropical Medicine, Medical University of Gdansk

ul. Powstania Styczniowego 9B, 81-519 Gdynia, Poland, tel: +48 58349 19 32, e-mail: mariajez@gumed.edu.pl 
tion greatly contributes to the high levels of stress. According to Korczyński [11], sea isolation is a difficult situation, which manifests itself as a short- or long-term interruption of the optimal stimulation level among mariners [12, 13]. It can cause temporary deformations or complete destruction of activity patterns, as well as temporary or long-term personality disorders or changes of a clearly pathological nature. According to mariners, separation from family during the voyage is the largest stress factor of the aforementioned isolation $[6,10]$. Such a separation results in the deprivation of basic emotional, social and physiological needs. It often leads to a feeling of frustration, which grows stronger with time. However, in terms of marital bonds, separation can serve 2 functions - positive and negative [6]. On the one hand, separation from marital partners can contribute to the intensification of feelings, idealisation of the partner, a longing transformed into emotional desire, while on the other, it can weaken the emotional bonds, cause several disruptions in mutual communication or a loss of trust. The primary factor determining the direction of the above-mentioned relation is the original quality of the emotional bond between the partners. In the case of badly matched marriages, characterised by weak emotional bonds, long-term and regularly repeated separation can constitute a significant hurdle on the way to marital success $[14,15]$.

The purpose of this study is to attempt to verify the correlation between the quality of emotional bonds, manifested in marital satisfaction, and the level of stress and anxiety experienced by mariners. This goal raise the following research question: is marital satisfaction an important inhibitor of stress and anxiety experienced by mariners? Based on current knowledge and previous research in this field, it was determined that marital satisfaction constitutes a buffer in the process of stress perception among mariners and minimises the level of perceived anxiety.

\section{MATERIALS AND METHODS}

The research was conducted in the years 2011-2012 among 210 mariners serving on seagoing ships. The surveyed mariners came mostly from the north of Poland. The age of the survey participants ranged from 25 to 60 years, while the marriage length oscillated between 1 and 35 years. Most survey participants had high school education (57.3\%) or university education (32.5\%) among officers, while $10.2 \%$ had basic vocational education. The study employed 3 research tools: State-Trait Anxiety Inventory (STAI) composed of 2 self-assessment scales measuring 2 types of anxiety - anxiety as a current state and anxiety as a relatively constant attitude towards the experience of anxiety states - this study employed only the factor of anxiety as a current state, understood as a dynamic emotional state of the individual, characterised by the subjective experience of stress and anxiety, accompanied by an increased activity of the autonomic nervous system [16]; Levestein's Stress Level Questionnaire (PS) adapted into Polish by Plopa [10], which, besides a general indication of the perceived stress, enables to determine the intensity in categories such as the feeling of tiredness, irritability, worrying, psychological stress, lack of joy of life, perception of pressure and overload [6]; and Rostowski's Well-matched Marriage Questionnaire (KDM), which enables to measure the degree of general marital satisfaction and the level of perceived love and happiness, the emotional bond with the partner, intimacy, similarity of behaviour, sexual satisfaction and the possession of children [10].

\section{RESULTS}

In the following model (Fig. 1), marital satisfaction (KDM) is treated as a variable serving as a mediator in the correlation between stress experienced in connection with the professional life of a mariner and the level of anxiety perceived and manifested by the surveyed persons.

Analysis results indicate that, in general, the model is sufficiently fitted to the data, and its efficiency is satisfactory (Fig. 1, Tables 1, 2).

In order to assess the mediating role of marital satisfaction in the development of correlations between stress and anxiety experienced by mariners, the researchers conducted an analysis, assessing the significance of direct effects and indirect effects through a 1000-fold bootstrap simulation. The results of the analysis are presented in Table 3.

As it is shown by the above Table 3 and Figure 1, the direct effect of stress connected with conducting the mariner's profession on the 'anxiety state' experienced by the surveyed persons was statistically significant $\beta=0.31$; $p<0.01$ ), but is much weaker in the context of the mariner's marital satisfaction (Indirect effect, $\beta=0.12 ; p<0.01$ ). Even though the total effect of stress on the anxiety experienced by the surveyed in the context of (through) marital satisfaction remains significant $(\beta=0.43 ; p<0.01)$, there are grounds for stating that there is a partial mediation of the variable 'marital satisfaction' with regard to the correlation of stress experienced due to mariner's work and the anxiety experienced by the surveyed persons. Thus, one can state that the quality of the mariner's marriage plays an important mediating role in the development of anxiety reactions to the experienced professional stress. Therefore, marital satisfaction can serve as a buffer in this correlation, partially inhibiting those reactions or, in the case of unsuccessful marriages, significantly intensifying the reactions.

\section{DISCUSSION}

The analysis of literature on the subject indicates a significant deficit of research concerning the correlation between the quality of the mariners' personal life and their 


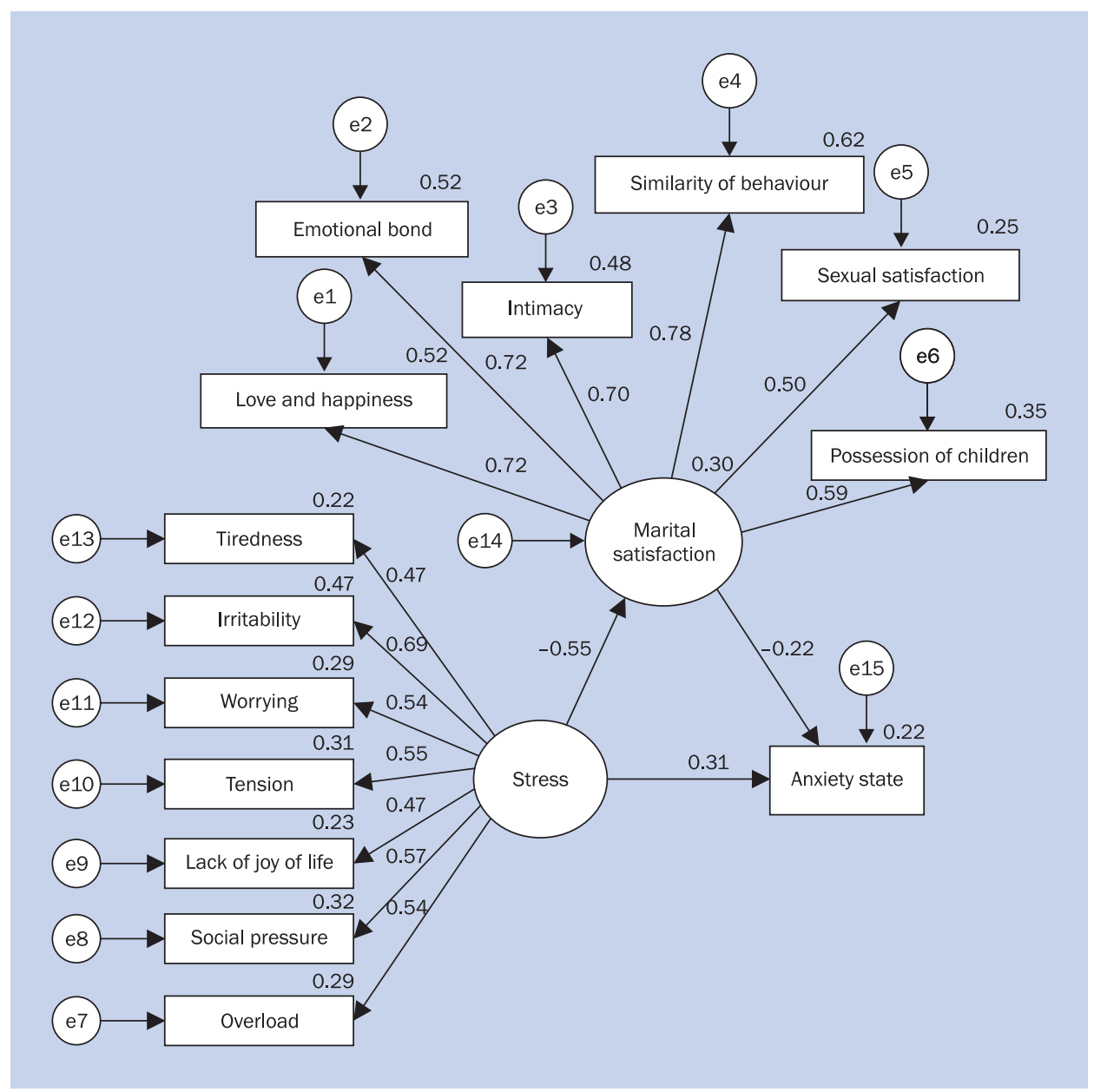

Figure 1. Path diagram presenting the results for the approximated model

Table 1. Indicators of global model fitting

\begin{tabular}{lllll}
\hline & CFI & RMSEA & GFI & AGFI \\
\hline$\chi^{2}(75)=136.7$ & 0.919 & 0.058 & 0.93 & 0.89 \\
$p=0.524$ & & & &
\end{tabular}

$\mathrm{CFI}$ - comparative fit index; RMSEA - root mean square error of approximation; $\mathrm{GFI}$ - goodness of fit index; AGFI - adjusted goodness of fit index

professional life on the ship. Research by Jeżewska et al. [17] indicate the existence of positive correlations between life satisfaction and the general quality of life, especially in the aspect of social relations, as well as the inhibiting effect of the subjective assessment of life quality on the psychological perception of work pressure. These findings match the results of the analyses conducted in this study, which revealed significant negative correlations between marital satisfaction and stress and anxiety experienced by mariners, as well as positive correlations between stress and anxiety state. The above-mentioned studies and many other studies concerning stress among mariners $[6,17]$ also indicate that when faced with professional problems and challenges at sea, mariners are more likely to employ constructive stress coping strategies determined by a task-oriented coping style, which significantly reduce the level of experienced anxiety and stress, rather than emotion-oriented coping styles, which can lead to behavioural disorganisation [17]. However, the results of comparison analyses within the scope of stress and anxiety perceived between the partners of mariner relationships indicate that mariners experience anxiety and environment pressure more often than their wives [6], which stems directly from the nature of their work [9]. Research concerning the mariners' personal life reveal that the wives of mariners exhibit higher marital satisfaction [6], which is not surprising, considering many sacrifices and stress factors to which the mariners are exposed, i.e. isolation, loneliness, need deprivation [12]. What is interesting is the fact, that when compared to non-mariner marriages (so-called "land" relationships), mariner marriages in general present a significantly higher level of marital satisfaction, despite many objective obstacles to this satisfaction [6]. These results may be interpreted in 2 ways: on the one hand, there may be a mechanism of rela- 
Table 2. Summary of the analysis of the model paths significance

\begin{tabular}{|c|c|c|c|c|c|c|c|}
\hline \multicolumn{3}{|l|}{ Correlation variables } & \multicolumn{5}{|c|}{ Correlation strength } \\
\hline Consequence & $\leftarrow$ & Cause & B & S.E.(B) & $\beta$ & $\mathbf{Z}$ & $\mathbf{p}$ \\
\hline Marital relations & $\leftarrow$ & Stress & -2.846 & 0.553 & -0.552 & -5.146 & $<0.001$ \\
\hline Love and happiness & $\leftarrow$ & Marital satisfaction & 1 & & 0.718 & & \\
\hline Emotional bond & $\leftarrow$ & Marital satisfaction & 0.621 & 0.067 & 0.719 & 9.307 & $<0.001$ \\
\hline Intimacy & $\leftarrow$ & Marital satisfaction & 0.595 & 0.066 & 0.695 & 9.023 & $<0.001$ \\
\hline Similarity of behaviour & $\leftarrow$ & Marital satisfaction & 0.756 & 0.075 & 0.784 & 10.035 & $<0.001$ \\
\hline Sexual satisfaction & $\leftarrow$ & Marital satisfaction & 0.151 & 0.023 & 0.503 & 6.612 & $<0.001$ \\
\hline Possession of children & $\leftarrow$ & Marital satisfaction & 0.238 & 0.031 & 0.594 & 7.772 & $<0.001$ \\
\hline Social pressure & $\leftarrow$ & Stress & 1 & & 0.566 & & \\
\hline Lack of joy of life & $\leftarrow$ & Stress & 1.159 & 0.221 & 0.475 & 5.251 & $<0.001$ \\
\hline Tension & $\leftarrow$ & Stress & 0.74 & 0.126 & 0.555 & 5.871 & $<0.001$ \\
\hline Worrying & $\leftarrow$ & Stress & 1.014 & 0.177 & 0.535 & 5.726 & $<0.001$ \\
\hline Irritability & $\leftarrow$ & Stress & 0.8 & 0.12 & 0.688 & 6.685 & $<0.001$ \\
\hline Feeling of tiredness & $\leftarrow$ & Stress & 0.555 & 0.106 & 0.472 & 5.225 & $<0.001$ \\
\hline Overload & $\leftarrow$ & Stress & 0.873 & 0.152 & 0.536 & 5.731 & $<0.001$ \\
\hline Anxiety state & $\leftarrow$ & Marital satisfaction & -0.045 & 0.019 & -0.216 & -2.368 & $<0.001$ \\
\hline Anxiety state & $\leftarrow$ & Stress & 0.333 & 0.108 & 0.31 & 3.085 & $<0.001$ \\
\hline
\end{tabular}

Table 3. Stress and anxiety - the mediating role of marital satisfaction

\begin{tabular}{llll} 
& \multicolumn{2}{c}{ Anxiety (State-Trait Anxiety Inventory) } & Total effect \\
\cline { 2 - 4 } & Indirect effect & Direct effect & $0.429 *$ \\
\hline Stress (Stress Experience Questionnaire) & $0.119 *$ & $0.31^{*}$ & 0.289 \\
Bottom threshold & 0.021 & 0.112 & 0.556 \\
Upper threshold & 0.227 & 0.509 &
\end{tabular}

${ }^{*} p<0.001$

tionship idealisation, while on the other hand, we can talk about the intensification of feelings, the strengthening of emotional bonds in the face of many difficulties encountered by maritime partners in everyday life.

However, these analyses failed to unequivocally determine the impact of personal life and its subjective assessment on the mariners' professional performance, especially stress coping, which was the basis of the presented studies. Based on the obtained results, one may conclude that the mariners' marital satisfaction plays a significant mediating role in the correlation between perceived stress and anxiety reactions. Thus, it appears that personal life of the mariners can positively impact their professional performance. In the opinion of mariners, marriage and family increase their ability to cope with many stressful situations at sea, reducing perceived stress and the likelihood of anxiety reaction. On the other hand, the low levels of marital satisfaction can generate negative experiences, intensifying the level of perceived stress and increasing the likelihood of anxiety reactions. Thus, on the basis of literature on the subject, one may conclude that high level of marital satisfaction can generate coping resources [2], what facilitate coping with difficult situations, problems, and psychological load arising from the nature of work at sea.

\section{CONCLUSIONS}

The frequently observed spillovers between mariners' professional and personal life can be both negative, determining the experience of various role conflicts and thus acting as an obstacle on the way to marital/family success, as well as positive, providing valuable coping resources, which support the individual in coping with stress. Based on the conducted research, it is possible to conclude that such positive spillovers exist among the surveyed mariners, and marital satisfaction constitutes a significant mediator in the correlation between perceived stress and the arising anxiety. 


\section{REFERENCES}

1. Poelmans S, Stepanova O, Maruda A. Positive spillover between personal and professional life: definitions, antecedents, consequences and strategies. In: Korabik JK, Lera DS, Whitehead DL eds. Handbook of work, family integration, research, theory and best practices. Elsevier, San Diego, CA 2008: 141-156.

2. Peplińska A, Rostowska T. Quality of life and relations between work and family. Acta Neuropsychologica 2013; 11: 77-92.

3. Peplińska A. Psychologiczne i zdrowotne konsekwencje równoważenia ról zawodowych i rodzinnych. In: Rostowska T, Budziński W eds. Zawodowe i zdrowotne problemy człowieka w różnych okresach dorosłości. Wydawnictwo Adam Marszałek, Toruń 2012: 64-85.

4. Jeżewska M, Iverson R. Stress and fatigue at sea versus quality of life. Int Marit Health 2012; 63: 106-115.

5. Borucki Z. Stres i przystosowanie w zawodzie marynarza. Przegl Psychologiczny 1972; 2: 63-74.

6. Peplińska A. Małżeństwo a specyfika pracy marynarzy: perspektywa psychologiczna. Oficyna Wydawnicza Impuls, Cracow 2011.

7. Leka S. Psychosocial hazards and seafarers health: priorities for research and practise. Int Marit Health 2004; 55: 137-154.

8. Leszczyńska I, Jeżewska M. Psychosocial burden among offshore drilling platform employees. Int Marit Health 2010; 61: 159-157.
9. Carotenuto A, Molino I, Fasanaro AM, Amenta F. Psychological stress in seafarers: a review. Int Marit Health 2012; 63: 188-194.

10. Plopa M. Stres w izolacji morskiej: psychospołeczne uwarunkowania. Wyd. UG, Gdańsk 1996.

11. Korczyński W. Psychofizyczna istota sytuacji izolacji morskiej. In: Psychofizyczne uwarunkowanie skuteczności działań na morzu. I Konferencja Naukowa, AMW, Pracownia Psychologiczna Marynark Wojennej, Gdynia 1988: 83-102.

12. Jeżewska M, Leszczyńska I, Jeremin B. Work-related stress at sea self estimation by maritime students and officers. Int Marit Health 2006; 57: 66-.75

13. Leszczyńska I, Jeżewska M, Jeremin B. Work-related stress at sea. Possibilities of research and measures of stress. Int Marit Health 2007; 58: 93-102.

14. Marks SR, Huston TL, Johnson EM, MacDermid SM. Role balance among white married couples. J Mariage Family 2001; 63: 1083-1098.

15. Rook K, Dooley D, Catalano R. Stress transmission: the effects of husbands' job stressors on the emotional health of their wives. J Marriage Family 1991; 53: 165-177.

16. Siek S. Wybrane metody badania osobowości. Akademia Teologii Katolickiej, Warsaw 1993

17. Jeżewska M, Leszczyńska I, Grubman-Nowak M. Personality and temperamental features vs quality of life of Polish seafarers. Int Marit Health 2013; 64: 101-155. 